\title{
Investigations of a D10 laboratory Farymann Diesel engine by means of a Langmuir probe
}

\begin{abstract}
A precise determination of the crankshaft angular position, at which the self fuel ignition occurs in a diesel engine, enables a credible diagnosis of the technical condition of the engine working space as well as the fuel feed system. An observation of the Langmuir probe signal provides entirely new possibilities for engine diagnostics. The probe is introduced into the working space of a cylinder through its indicator valve.

This paper presents preliminary results of diagnostic tests performed on a D10 type Farymann Diesel engine. The main aim of the investigations was to confirm the diesel engine control susceptibility to the applied, original measuring method that enables a precise determination of the crank-shaft angle, under which the fuel self-ignition occurs. In order to verify the diagnostic results, simultaneous measurements have been conducted of the cylinder pressure as well as vibrations (measured on the cylinder head cover or its mounting bolts) generated by the engine fuel injection system and the valve timing system.

A satisfactory qualitative and quantitative agreement of the recorded control parameters has been obtained using a simplified comparative analysis. The results showed that further upgrade of the diagnostic method as well as the computer software is necessary in order to synchronize all the monitored variables and enable a comparative analysis in relation to the angular crankshaft position.
\end{abstract}

Key words: technical diagnostics, diesel engine, investigations of working processes, Langmuir probe

\section{Badania diagnostyczne silnika laboratoryjnego Farymann Diesel D10 z zastosowaniem sondy Langmuira}

\begin{abstract}
Precyzyjne wyznaczenie położenia kątowego wału korbowego, przy którym następuje samozapłon paliwa silnika o ZS to podstawowy warunek sformułowania wiarygodnej diagnozy o stanie technicznym jego przestrzeni roboczych oraz układu zasilania paliwem. Całkowicie nowe możliwości w tym względzie wnosi obserwacja sygnału sondy Langmuira, która wprowadza się do przestrzeni roboczej cylindra przez zawór indykatorowy. W niniejszym artykule zaprezentowano wstępne wyniki badań diagnostycznych silnika laboratoryjnego Farymann Diesel D10 z zastosowaniem tej metody. Podstawowym celem badań byto potwierdzenie podatności kontrolnej silnika o ZS na zastosowanie całkowicie oryginalnej metody pomiarowej, która umożliwia precyzyjne wyznaczenie kąta samozapłonu paliwa. Dla weryfikacji informacyjności diagnostycznej uzyskanych wyników pomiarowych przeprowadzono jednoczesne pomiary ciśnienia cylindrowego oraz drgań generowanych z uktadu wtryskowego i rozrzadu zaworowego silnika (mierzonych na pokrywie głowicy lub jej śrubach ściagowych). W wyniku uproszczonej analizy porównawczej uzyskano zadowalajaca zgodność jakościowa $i$ ilościowa zarejestrowanych przebiegów obserwowanych parametrów kontrolnych. Uzyskane doświadczenia badawcze wskazuja na konieczność dalszej modernizacji metody pomiarowej oraz oprogramowania komputerowego, tak aby możliwe było precyzyjne zsynchronizowanie rejestracji wszystkich wielkości pomiarowych, umożliwiajace dokonanie analizy porównawczej ich przebiegów względem położenia kątowego watu korbowego.

Słowa kluczowe: diagnostyka techniczna, tłokowy silnik spalinowy o ZS, badanie procesu roboczego, sonda Langmuira
\end{abstract}

\section{Introduction}

The investigations of the ionization processes in hydrocarbon/air flames already have a long history [1-19]. The value of the studies on the combustion plasma is related to a possible application of ion probes in the control of the combustion [16] with the benefit of reducing the significant environmental effects caused by the exhaust emissions [13-15]. Recent studies have demonstrated some prospective applications of ion (Langmuir) probes in the measurement of the flame characteristics [16-18]. In particular, the local equivalence fuel/air ratio at the early stage of flame kernel development has been derived from the ion probe measure-

\section{Wprowadzenie}

Badania procesów jonizacji w płomieniach węglowodorowych posiadają już długą historię [1-19]. Zainteresowanie plazmą powstającą we froncie spalania wynika $\mathrm{z}$ efektów środowiskowych związanych z emisją gazów wydechowych [13-15] oraz z możliwości kontroli procesu spalania za pomocą sond Langmuira [16]. Najnowsze badania wskazują na możliwość zastosowania sond dla pomiaru charakterystyk płomienia [16-18]. W szczególności, pomiary sondą Langmuira umożliwiły określenie lokalnej wartości stosunku paliwa do powietrza w początkowym etapie rozwoju płomienia [16]. Skalibrowany sygnał sondy 
ments [16]. Calibrated probe signals have also been used to measure the quenching distance during head-on flame quenching [17]. The ion probe technique combined with Schlieren diagnostics enables a measurement of the combustion velocity in a model combustion chamber [18].

One of the first attempts to commercialize ion probe diagnostics in internal-combustion engines was done by Honda R\&D Co. and NGK Spark Plug Co. [12]. According to their report the studied spark-plug-voltage analysis system enables continuous control of the combustion. The application of ion probes for diagnostics of combustion in Diesel engines has recently been proposed by Estefanous [20].

The main ionization channel in hydrocarbon flames is related to its chemi-ionization process otherwise known as the Calcote mechanism:

$$
\mathrm{CH}+\mathrm{O}=\mathrm{CHO}^{+}+\mathrm{e}^{-}
$$

This explains why the signal in hydrogen flames (related to thermal ionization) is negligible. A comprehensive study of ion formation during combustion of propane/air mixtures based on mass-spectrometric measurements as well as on numerical modeling of chemi-ionization processes was carried out in ref. 19. The ionization reaction (1) is followed by a series of plasma-chemical processes leading to an abundance of various negative and positive ions. It was reported that the most abundant charged species in the flame front region for stoichiometric propane/air mixture are $\mathrm{C}_{2} \mathrm{H}_{3} \mathrm{O}^{+}$, $\mathrm{HCO}^{2-}$ ions and electrons. By increasing the distance from the flame front the ion composition changes significantly. In the burnt gas region the major charged species are $\mathrm{H}_{3} \mathrm{O}^{+}$, $\mathrm{NO}^{+}, \mathrm{CO}_{3}^{-}, \mathrm{HCO}_{3}^{-}$ions and electrons. The concentration of $\mathrm{C}_{2} \mathrm{H}_{3} \mathrm{O}^{+}, \mathrm{HCO}_{3}^{-}$ions and electrons grows with the increase of the equivalence ratio.

\section{Langmuir probe indicates existing charge species in Diesel engine cylinder}

As discussed above one can expect various charge species in a flame front also in a cylinder of a selfignition engine (SIE). Therefore, when a Langmuir probe (LP) is introduced to the cylinder space of an SIE a current, $I_{\text {pol }}$, will appear in the electric circuit of the probe, under hydrocarbon flame conditions.

A Langmuir probe is a metal electrode polarized by a probe voltage $U_{\text {pol }}$. The engine walls usually become a second polarization electrode, hence, the LP should be isolated from the walls. The current of the probe, $\mathrm{I}_{\mathrm{pol}}$, can be analyzed using a simple recording diagram as shown in Fig. 1. An oscilloscope presents and records changes of the voltage $\mathrm{U}_{\mathrm{wZ}}$ that occurs at the resistor $\mathrm{R}_{\mathrm{wZ}}$ as a result of current Ipol in the circuit.

\section{Connecting of the Lagmuir probe to an SI engine}

Figure 2 presents design details of a Langmuir probe introduced to the cylinder space of an diesel engine. In the case of the Farryman Diesel D10 engine był również wykorzystany dla określenia odległości gaszenia w przypadku czołowego frontu spalania [17]. Sondy Langmuira w kombinacji ze spektroskopią Schlierena umożliwia pomiar prędkości frontu spalania w modelowej komorze spalania [18].

Jedną z pierwszych prób komercjalizacji diagnostyki sond Langmuira w silnikach wewnętrznego spalania dokonano w firmie Honda R\&D Co. i NGK Spark Plug Co. [12]. Zgodnie z raportem układ analityczny wykorzystujący napięcie z sondy wykorzystującej świecę zapłonową umożliwia ciągłą kontrolę procesu spalania. Zastosowanie sond Langmuira dla diagnostyki silników Diesla zaproponowano ostatnio w pracy doktorskiej Estafanosa [20].

Głównym kanałem jonizacji w płomieniach węglowodorowych jest proces chemo-jonizacji, tak zwany mechanizm Calcote'a - wzór (1).

Fakt ten wyjaśnia dlaczego w płomieniach wodorowych (związanych z termo-jonizacją) sygnał prądowy jest zaniedbywalnie mały. Szerokie badania procesów jonizacji i kinetyki jonowej w płomieniu propan/powietrze przeprowadzono $\mathrm{z}$ wykorzystaniem spektroskopii masowej oraz modelowania numerycznego - patrz ref. 19. Reakcja jonizacji (1) zapoczątkowuje cały szereg plazmo-chemicznych procesów prowadzących do powstania różnych jonów dodatnich i ujemnych. W pracy wykazano, że we froncie spalania propan/powietrze najliczniejszymi cząstkami naładowanymi są jony $\mathrm{C}_{2} \mathrm{H}_{3} \mathrm{O}^{+}, \mathrm{HCO}_{2}^{-}$i elektrony. Wraz z odległością od frontu spalania coraz bardziej zmienia się skład jonowy. W regionie gazów spalinowych najczęstszymi jonami są $\mathrm{H}_{3} \mathrm{O}^{+}, \mathrm{NO}^{+}, \mathrm{CO}_{3}^{-}, \mathrm{HCO}_{3}^{-}$oraz elektrony. Co więcej koncentracja jonów $\mathrm{C}_{2} \mathrm{H}_{3} \mathrm{O}^{+}, \mathrm{HCO}_{3}^{-}$ oraz elektronów rośnie ze malejącym współczynnikiem nadmiaru powietrza.

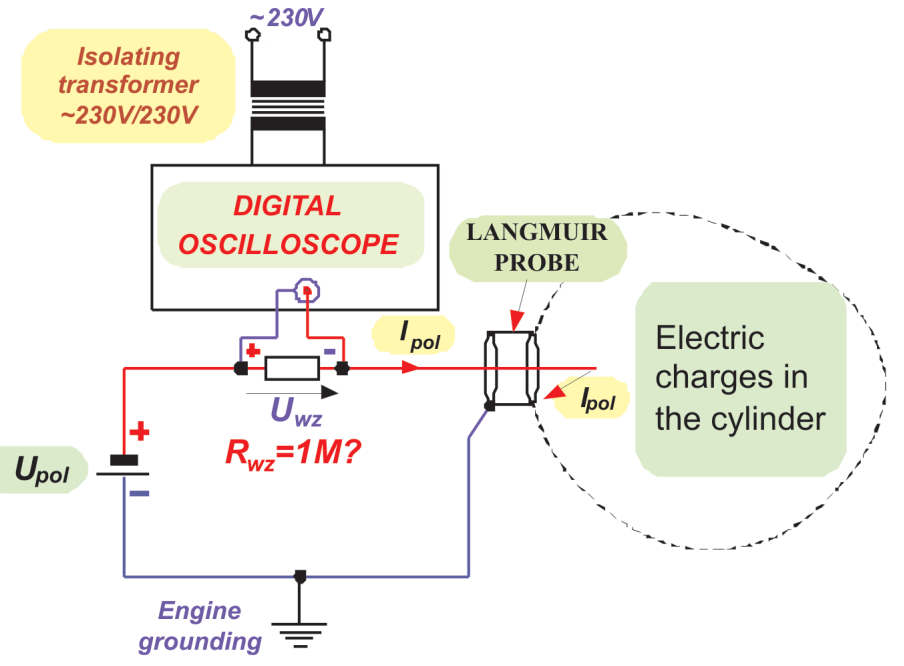

MEASURING SYSTEM WITH LANGMUIR PROBE

Fig. 1. The Langmuir probe circuit and the recording set-up with oscilloscope Rys. 1. Układ pomiarowy z sonda Langmuira i rejestracja zmian prądu $I_{\text {pol }}$ na ekranie oscyloskopu 
considered here, the Langmuir probe was introduced to the cylinder space through an existing hole enabling such an introduction. The hole enables mounting of the indicator-valve that usually serves the purpose of electronic cylinder pressure measurements. A direct contact with the cylinder space where the fuel combustion take place forces considerable design constraints of the Langmuir probe including:

1. The LP should be well insulated from the engine walls. The insulation should be resistant to possible soot formation between the probe and the walls. Due to the high conductivity of soot particles, soot paths could lead to an electrical shortcut between the LP and the walls; the LP signal decay.

2. The LP should be mounted tightly in order to provide an airtight seal and protection from the high working pressures within the cylinder.

3. The high temperatures inside the cylinder present severe constraints that would need to be overcome to avoid rapid mechanical wear of the materials.

Taking into account the above mentioned constraints and conditions the decision has been made to use a modified spark plug (used in gasoline engines) as the LP. Standard spark plug design provides resistivity of its electrodes and electric circuit to high pressure and temperature conditions. Equally important is the relative low cost and easy access to a Langmuir probe of this type.

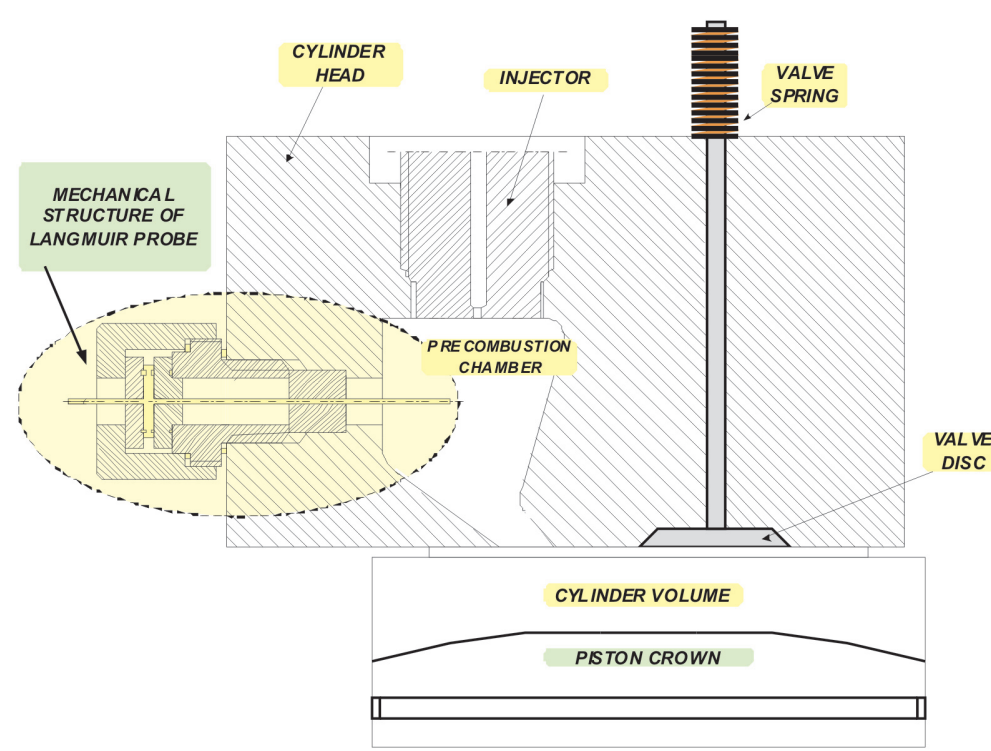

Fig. 2. A diagram of the Langmuir probe introduced to the cylinder space of a diesel engine

Rys. 2. Szkic konstrukcyjny sondy Langmuira wprowadzanej do przestrzeni cylindra silnika $Z S$

Figure 3 presents the design of the Langmuir probe.

Figure 4 and 5 present the way of mounting of the discussed Langmuir probe to the cylinder of the diesel engine used in this experiment. The metallic adapter in Fig. 5 enables a simultaneous measurement of the LP probe signal and the pressure by an electronic engine indicator.

\section{Sonda Langmuira wykrywająca istnienie ladunków elektrycznych w cylindrze silnika ZS}

Przedstawiona w poprzednim punkcie analiza wskazuje na możliwość występowania ładunków elektrycznych we froncie spalania w cylindrze silników o ZS. Jeżeli sonda Langmuira zostanie wprowadzona do przestrzeni cylindra, to w przypadku zainicjowania płomienia węglowodorowego, w obwodzie elektrycznym sondy pojawi się prąd $\mathrm{I}_{\mathrm{pol}}$. Sondę Langmuira tworzy elektroda metalowa spolaryzowana napięciem $\mathrm{U}_{\text {pol }}$. Kadłub silnika stanowi zazwyczaj drugą elektrodę, dlatego sonda winna być izolowana względem tego kadłuba. Prosty układ pomiarowy przedstawiony na rys. 1 umożliwia obserwację zmian prądu $\mathrm{I}_{\text {pol }}$. Oscyloskop umożliwia obserwację i rejestrację napięcia $U_{w z}$ pojawiającego się na oporniku $\mathrm{R}_{\mathrm{wZ}}$, na skutek przepływu prądu $\mathrm{I}_{\mathrm{pol}}$.

\section{Sposób montażu sondy Langmuira w strukturze silnika o ZS}

Rysunek 2 przedstawia szkic konstrukcyjny sondy Langmuira wprowadzanej do przestrzeni cylindra silnika ZS. W przypadku badanego typu silnika Farryman Diesel D10 wykorzystano do tego celu istniejący otwór w głowicy, umożliwiający wprowadzenie sondy Langmuira do przestrzeni cylindra. Otwór ten służy standardowo do wkręcenia kurka indykatorowego, umożliwiającego przyłączenie elektronicznego indykatora ciśnienia w cylindrze. Bezpośredni dostęp do przestrzeni cylindra, w którym zachodzi spalanie paliwa, narzuca szczególne wymagania konstrukcyjne sondy Langmuira:

Sonda Langmuira musi być odizolowana od kadłuba silnika. Izolacja nie może być zniwelowana na skutek osadzania się cząsteczek sadzy pomiędzy elektrodą środkową i kadłubem silnika. Ze względu na bardzo dobrą przewodność elektryczną cząstek sadzy może nastąpić zwarcie elektryczne pomiędzy sondą Langmuira i kadłubem silnika i zanik sygnału,

Montaż sondy Langmuira musi zapewnić bardzo dobrą szczelność i odporność na oddziaływanie wysokich ciśnień w przestrzeni cylindrowej.

Istotnym ograniczeniem jest też wysoka temperatura występująca wewnątrz cylindra przyspieszająca mechaniczne zmęczenie materiału.

Biorąc pod uwagę powyższe, zdecydowano się na wykorzystanie odpowiednio zaadaptowanej świecy zapłonowej stosowanej w klasycznych silnikach o zapłonie iskrowym. Konstrukcja części mechanicznej świecy zapłonowej zapewnia odporność jej elektrod (i układu elektrycznego) na oddziaływanie wysokich ciśnień i temperatur. Nie do przecenienia jest niski koszt oraz rynkowa dostępność sond Langmuira tego typu. Sondę Langmuira zbudowaną zgodnie z tymi wymaganiami przedstawia rys. 3 .

Rysunki 4 i 5 przedstawiają sposób montażu sondy Langmuira do ścianki cylindra silnika o ZS zastosowanego do testów pomiarowych. Rysunek 5 przedstawia metalowy 


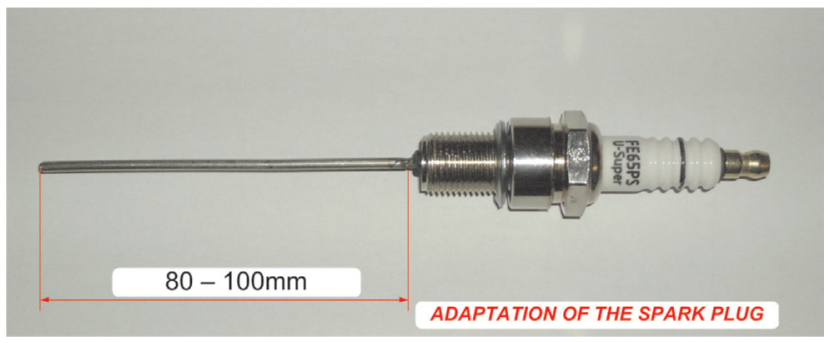

Fig. 3. The Langmuir probe based on a standard spark plug Rys. 3. Konstrukcja sondy Langmuira z wykorzystaniem świecy zapłonowej silnika ZI

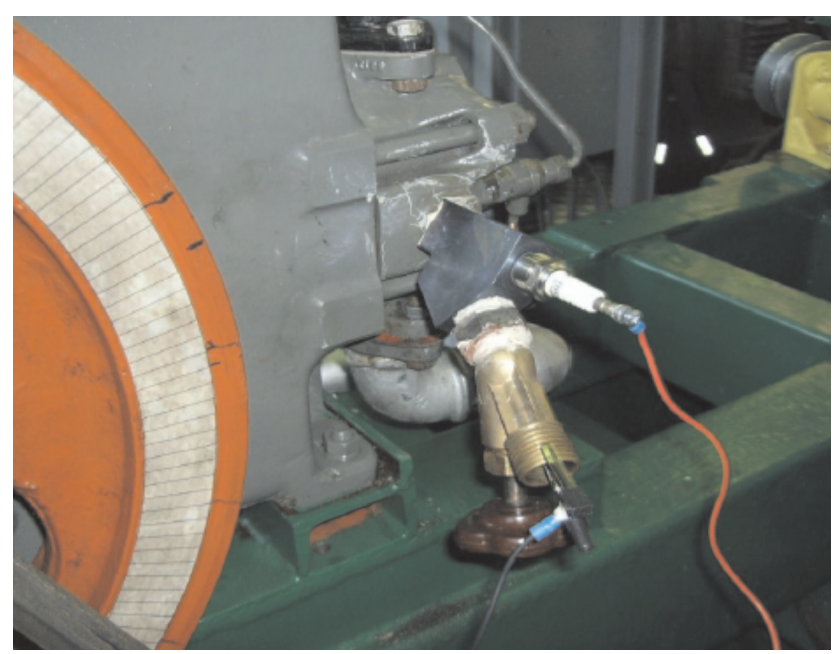

Fig. 5. Metallic adapter enabling a simultaneous measurement of the LP probe signal and the pressure by an electronic engine indicator

Rys. 5 Widok adaptera umożliwiajacego wstawienie kurka indykatorowego i jednoczesny pomiar ciśnienia indykowanego

\section{Results of the measurements for the set-up with Langmuir probe}

Figures 6 and 7 present the registered Langmuir probe signals. Additionally, as a point of reference, the signal measuring position of the Top Dead Centre (TDC) of the engine was assumed. The analysis of the resulting figures

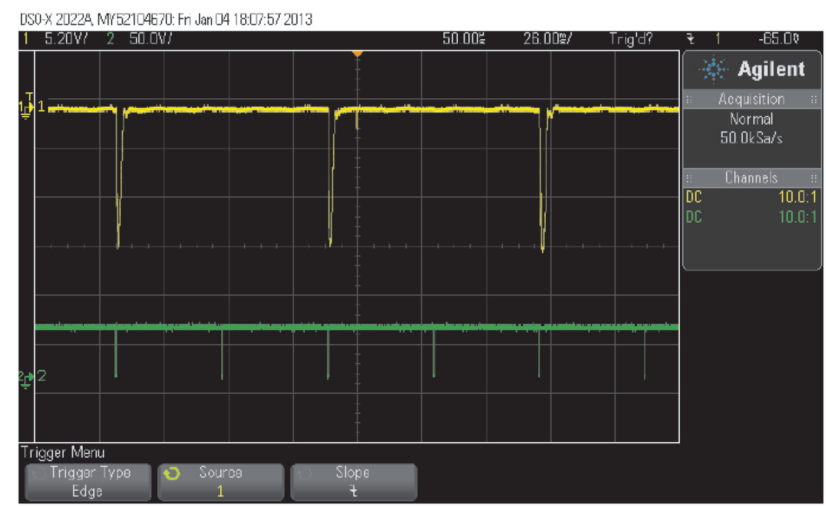

Fig. 6. The Langmuir probe signals (above) and the TDC pulses (below) measured for the Farryman D10 Diesel engine

Rys. 6. Sygnały sondy Langmuira (przebieg górny) i impulsy układu GMP silnika Farryman Diesel D10 (przebieg dolny)

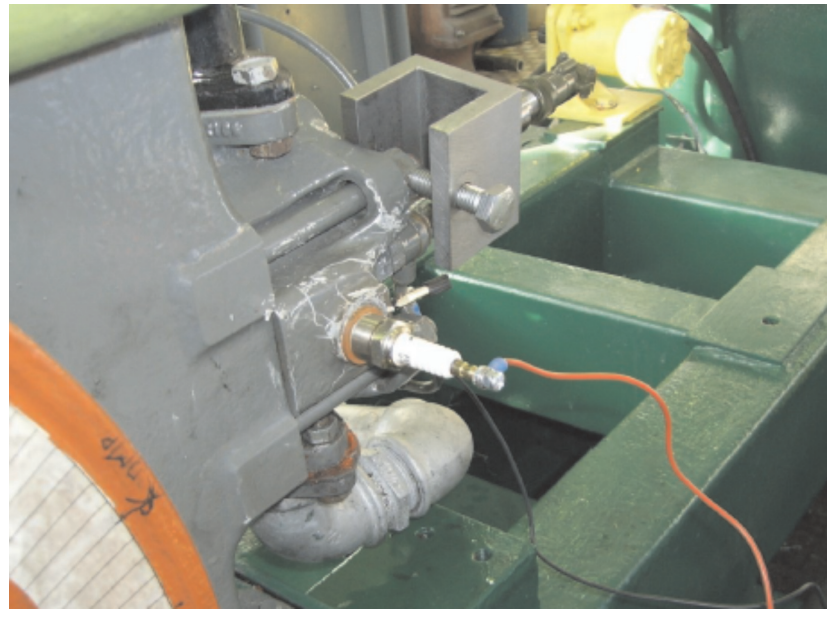

Fig. 4. Langmuir probe mounted in the cylinder of a Farryman Diesel D10 engine

Rys. 4. Sonda Langmuira umieszczona w cylindrze silnika Farryman Diesel D10

adapter umożliwiający jednoczesne indykowanie silnika z zastosowaniem elektronicznego miernika ciśnienia.

\section{Wyniki pomiarów otrzymanych dla układu z sondą Langmuira}

Rysunki 6 i 7 przedstawiają zarejestrowane sygnały sondy Langmuira. Dodatkowo wprowadzono, jako sygnał odniesienia, sygnał uzyskany z układu pomiarowego górnego martwego punktu (GMP) silnika. Analiza tych rysunków wskazuje na występowanie stromego czasowego zbocza sygnału pomiarowego, wskazującego bezpośrednio na rozpoczęcie procesu spalania paliwa w cylindrze silnika o ZS. Czas narastania sygnału oszacowano na ok. $0,1 \mathrm{~ms}$. To umożliwia stosunkowo precyzyjnie określić moment samozapłonu w badanym silniku z ZS.

\section{Koncepcje budowy miernika kąta samozapłonu paliwa w cylindrze silnika o ZS}

Rysunek 8 przedstawia schemat układu pomiarowego kąta samozapłonu paliwa $\mathrm{z}$ zastosowaniem sondy Lang-

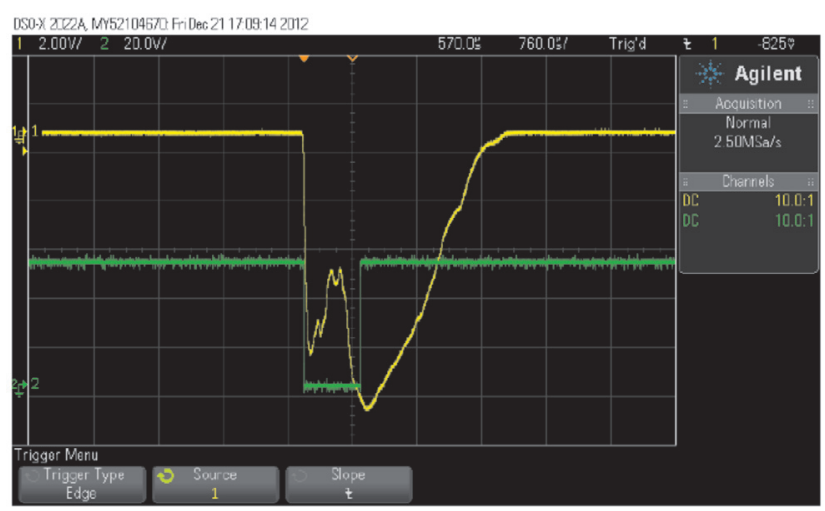

Fig. 7. The Langmuir probe signals (above) and the TDC pulses (below) measured for the Farryman D10 Diesel engine at greater time resolution

Rys. 7. Sygnały sondy Langmuira (przebieg górny) i impulsy układu GMP silnika Farryman Diesel D10 (przebieg dolny) w powiększeniu 
points to the existence of a temporary-steep signal rise, which probably indicates a combustion ignition in the engine cylinder. A signal rise time of the order of $0.1 \mathrm{~ms}$ can be estimated. It allows a relatively precise determination of the moment of self-ignition in the engine.

\section{The concept of an indicator of fuel self- ignition in a cylinder of a diesel engine}

Figure 8 presents a schematic of the set-up to measure the crankshaft angular position for the fuel self-ignition applying a Langmuir probe together with a simultaneous measurement of the pressure by the electronic engine indicator and vibrations generated in the cylinder head. An important additional element in this set-up is the TDC signal generator. A schematic of the TDC signal generator is presented in Fig. 9. The TDC signal generator helps to find temporal correlation between the signals of the electronic engine indicator measuring the pressure and the detector of the vibrations generated in the cylinder head.

A very important aspect of the TDC signal generator is related to galvanic separation between the TDC signals transmitted to the electronic engine indicator, the detector of the vibrations and to one of the oscillator inputs. The set-up shown in

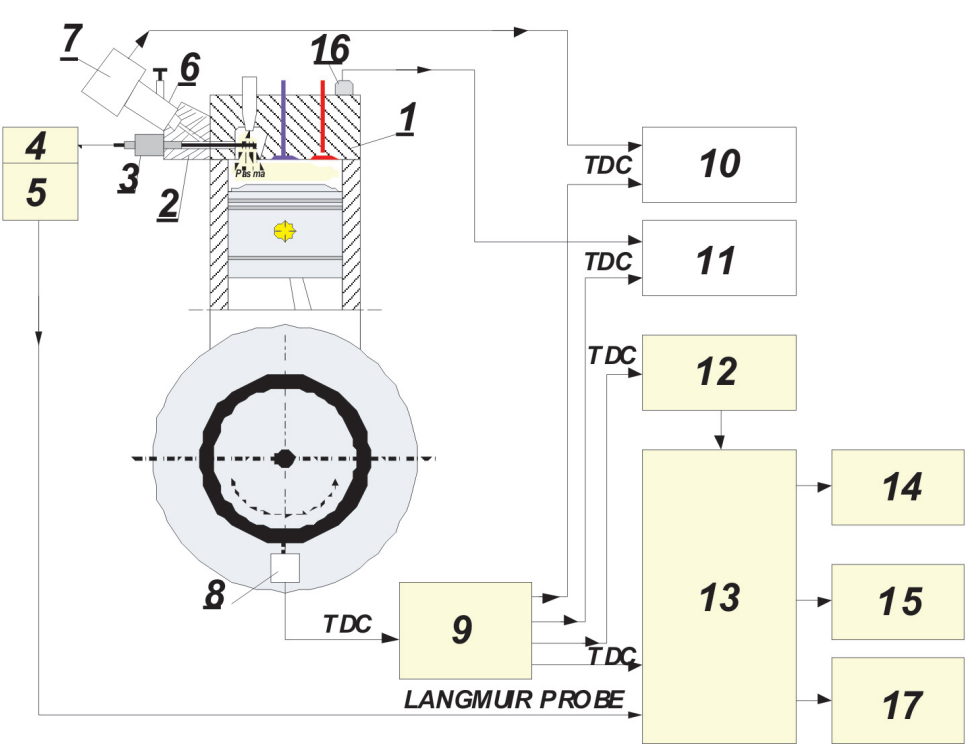

Fig. 8. A diagram of the set-up to measure the crankshaft angular position for fuel self-ignition together with a simultaneous measurement of the pressure by an electronic engine indicator and the vibrations generated in the cylinder head: 1 - cylinder head, 2 - adapter, 3 - Langmuir probe, 4 - power supply, 5 - amplifier, 6, 7 - electronic indicator, 8 - inductive sensor, 9 - TDC signal divider, 10 - pressure recorder, 11 - vibration recorder, 12 - timing of the crankshaft revolution, 13 - self-ignition angle measurement, 14 - tachometer, 15 - digital display of the self-ignition angle, 16 - accelerometer, 17 - data export

Rys. 8. Schemat układu miernika kąta samozapłonu paliwa z jednoczesnym pomiarem ciśnienia w cylindrze i rejestracja drgań

Fig. 8 determines the TDC of the cylinder using a reference indicator on the engine flywheel. In the case under consideration an M6 screw head, fixed in the appropriate position on the engine flywheel, was used as a marker. An inductive detector identifies and determines the screw head position. However, such a system leads to a rather significant error in measuring of the crankshaft angular position for fuel self-ignition. Taking into account the relative diameter of the screw head and the diameter of the flywheel, the uncertainty of the TDC determination can reach as much as $1.5 \mathrm{deg}$ of the crankshaft angle

A different concept to measure the crankshaft angular position for the fuel self-ignition in a cylinder of a diesel engine connected with simultaneous measurements of the

muira $\mathrm{w}$ połączeniu z jednoczesnym pomiarem ciśnienia indykowanego i pomiarem drgań generowanych $\mathrm{z}$ głowicy cylindrowej. Istotnym dodatkowym elementem zastosowanym w tym układzie pomiarowym jest dystrybutor sygnału GMP. Schemat ideowy dystrybutora sygnału GMP przedstawia rysunek 9. Dystrybutor sygnału GMP zapewnia określenie korelacji czasowej pomiędzy sygnałami rejestrowanymi w układzie elektronicznego miernika ciśnienia cylindrowego i rejestratora drgań głowicy cylindrowej.

Bardzo istotnym elementem w konstrukcji dystrybutora jest zapewnienie separacji galwanicznej pomiędzy sygnałami GMP przekazywanymi do układu miernika ciśnienia, rejestratora drgań i jednego z wejść oscyloskopu. W układzie z rysunku 8 określenie GMP dla cylindra odby-

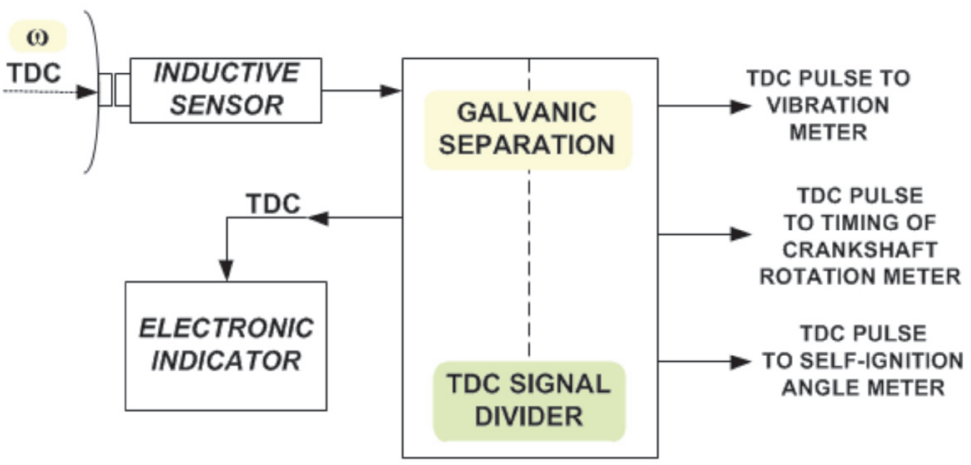

Fig. 9. Block diagram of the TDC signal divider Rys. 9. Schemat blokowy dystrybutora sygnatu GMP wa się przez umieszczenie znacznika na kole zamachowym silnika. W przypadku badanego silnika wykorzystano łeb śruby M6 wkręconej w odpowiednie miejsce (tożsame z GMP) na kole zamachowym silnika. Czujnik indukcyjny identyfikuje i lokalizuje łeb śruby wkręconej w koło zamachowe. W takim układzie określania GMP silnika, popełnia się znaczny błąd określenia kąta samozapłonu paliwa. Biorąc pod uwagę szerokość łba śruby i średnicę koła zamachowego, niejednoznaczność określenia punktu GMP wynosi około $1,5^{\circ} \mathrm{OWK}$.

Inną koncepcję budowy miernika kąta samozapłonu paliwa w cylindrze silnika o ZS, w połączeniu z jednoczesnym pomiarem ciśnienia 
pressure by an electronic engine indicator and the vibrations has been presented in Fig. 10. The important additional element applied in this case is a pulsed, rotating transducer generating 3600 pulses/crankshaft revolution (resolution $0.1 \mathrm{deg}$ of the crankshaft angle). The main advantage of this solution is related to the fact that the TDC signal is generated directly by the structure of the pulsed, rotating transducer. This increases the precision of the TDC determination to 0.1 deg of the crankshaft angle. Some errors can arise from the torsional vibrations of the connections between the engine and the pulsed, rotating transducer. The TDC signal generator applied here also ensures a determination of the temporal relations between the signals recorded by the electronic engine indicator and by the vibration detector.

\section{Methods of determination of the crankshaft angular position for fuel self-ignition}

\subsection{Determination of the LP pulse delay or advance versus the TDC pulse}

Figure 11 presents the method of determination of the crankshaft angular position for fuel self-ignition by a determination of time ti of advance or delay of the LP versus the TDC signal. Period $\mathrm{T}$ of a full crankshaft revolution should also be measured (see Fig. 12).

The angle of advance (in deg of the crankshaft angle $-{ }^{\circ} \mathrm{CA}$ ) or delay of the self-ignition is calculated from the equation:

$$
\alpha\left[{ }^{\circ} \mathrm{CSA}\right]=\frac{\mathrm{t}_{\mathrm{i}}}{\mathrm{T}} \cdot 360^{\circ}
$$

\subsection{Measurement of the number of pulses from the}

pulsed, rotating transducer

Figure 13 presents the measurement of the number of pulses Ni determining the advance or delay of the LP versus the TDC signal.

In this case, the angle $\alpha\left[{ }^{\circ} \mathrm{CA}\right]$ is determined by the number of pulses from the pulsed, rotating transducer; there is no need to measure period $\mathrm{T}$ of a full crankshaft revolution:

$$
\alpha\left[{ }^{\circ} \mathrm{CSA}\right]=\frac{\mathrm{N}_{\mathrm{i}}}{3600} \cdot 360^{\circ}=\frac{\mathrm{N}_{\mathrm{i}}}{10}
$$

\section{Final remarks and conclusions}

The application of a Langmuir probe enables an accurate estimation of the moment of fuel self-ignition in the cylinder of a diesel engine and provides a new diagnostic tool for a reliable diagnosis of an engine technical condition. A precise determination of the crankshaft angle at which the fuel selfignition occurs is a fundamental condition for a formulation credible diagnosis of the technical condition of the engine working space and its fuel feed system.

indykowanego i pomiarem drgań przedstawia rys. 10. Istotnym dodatkowym elementem zastosowanym w tym układzie pomiarowym jest przetwornik impulsowo-obrotowy generujący 3600 impulsów/1 obrót wału korbowego (rozdzielczość $\left.0,1^{\circ} \mathrm{OWK}\right)$. Istotą tego rozwiązania jest generowanie impulsu GMP bezpośrednio przez strukturę przetwornika impulsowo-obrotowego. W ten sposób można zmniejszyć niedokładność określenia GMP silnika do $0,1^{\circ} \mathrm{OWK}$. Pewne błędy pomiarowe mogą wnosić drgania skrętne połączenia pomiędzy silnikiem a przetwornikiem impulsowo-obrotowym. Zastosowany także w tym rozwiązaniu dystrybutor sygnału GMP zapewnia określenie wzajemnej relacji czasowej pomiędzy sygnałami rejestrowanymi w układzie elektronicznego miernika ciśnienia i rejestratora drgań.

\section{Metody określenia kąta samozapłonu paliwa}

6.1. Pomiar czasu opóźnienia lub wyprzedzenia impulsu otrzymywanego z sondy Langmuira względem impulsu GMP

Rysunek 11 przedstawia zasadę określania kąta samozapłonu paliwa poprzez pomiar czasu ti opóźnienia lub wyprzedzenia impulsu otrzymywanego z sondy Langmuira względem impulsu GMP. Dodatkowo należy wykonywać pomiar czasu trwania okresu T jednego pełnego cyklu obrotu wału korbowego silnika, co przedstawiono na rys. 12. Kąt $\alpha\left[{ }^{\circ} \mathrm{OWK}\right]$ wyprzedzenia lub opóźnienia samozapłonu oblicza się ze wzoru (2).

\subsection{Pomiar liczby impulsów otrzymywanych \\ z przetwornika impulsowo-obrotowego}

Rysunek 13 przedstawia zasadę pomiaru liczby impulsów Ni określających wyprzedzenie bądź opóźnienie impulsu z 


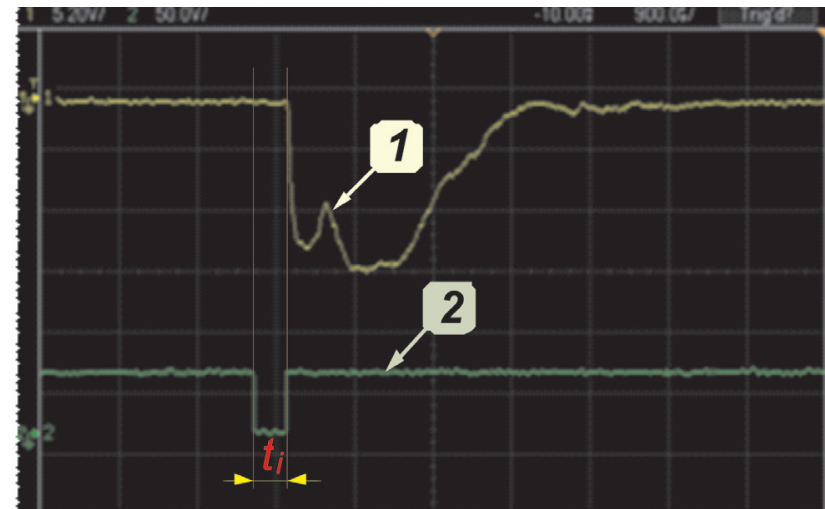

Fig. 11. Determination of the advance or delay time $t_{i}$ of the Langmuir probe versus the TDC signal

Rys. 11. Określenie czasu t wyprzedzenia lub opóźnienia impulsu otrzymywanego z sondy Langmuira względem impulsu GMP

In order to verify the diagnostic results, simultaneous measurements have been conducted of both the cylinder pressure and the vibrations (measured on the cylinder head cover or its mounting bolts) generated by the engine fuel injection system and the valve timing system.

A satisfactory qualitative and quantitative agreement of the registered control parameters has been obtained using a simplified comparative analysis. The results show that further modernization of the diagnostic method as well as the computer software is necessary in order to synchronize all

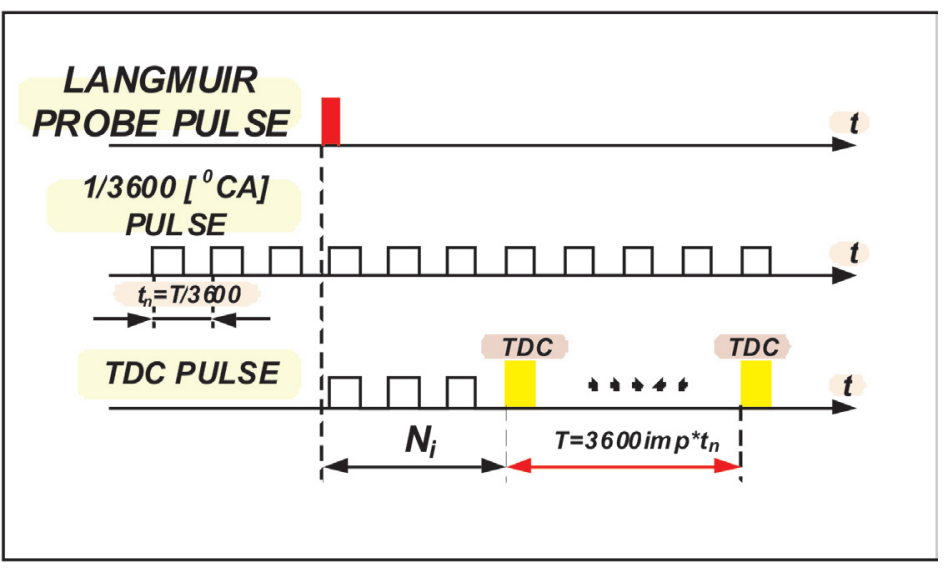

Fig. 13. The measurement method of the number of pulses $\mathrm{N}_{\mathrm{i}}$ determining the advance or delay of the LP versus the TDC signal

Rys. 13. Zasada pomiaru ilości impulsów $N_{i}$ określających wyprzedzenie bądź opóźnienie impulsu z sondy Langmuira względem impulsu GMP

the measuring quantities and enable a comparative analysis in relation to the angular crankshaft position.

In the future, diagnostics will be validated for similar biofuel engines.

\section{Acknowledgment}

The research works have been financed from the budget of a Research Task number 4 'Development of integrated technologies of fuel and energy production from biomass, agricultural waste and other' within the strategic project of scientific research and development works 'Advanced technologies of energy production' carried

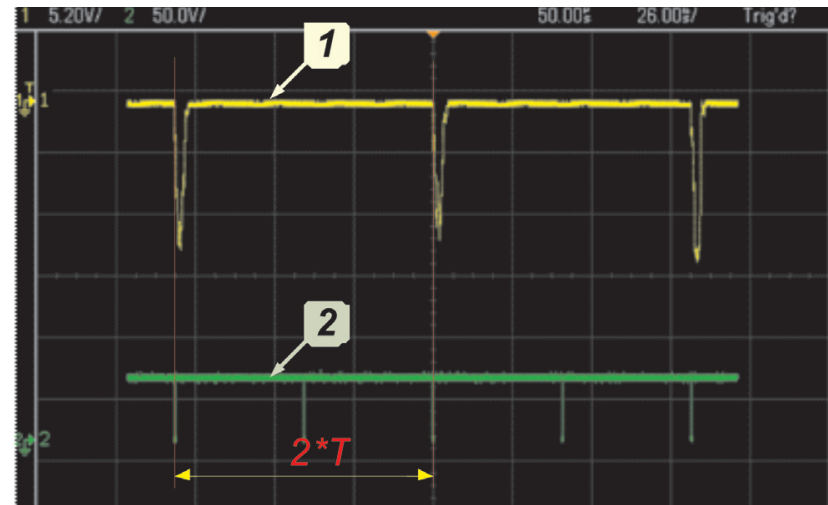

Fig. 12. Determination of a full crankshaft-revolution period $\mathrm{T}$ Rys. 12. Okré́lenie czasu T trwania jednego petnego obrotu wału korbowego silnika

sondy Langmuira względem impulsu GMP. W tym przypadku kąt $\alpha\left[{ }^{\circ} \mathrm{OWK}\right]$ określa liczba impulsów otrzymywanych z przetwornika impulsowo-obrotowego; nie ma konieczności pomiaru okresu T obrotu wału korbowego silnika - wzór (3).

\section{Uwagi końcowe i wnioski}

Zastosowanie sondy Langmuira umożliwia zgrubne oszacowanie chwili wystąpienia samozapłonu paliwa w cylindrze silnika o ZS, co daje nowe możliwości diagnostyczne w ocenie stanu technicznego silnika.

Precyzyjne wyznaczenie położenia kątowego wału korbowego, przy którym następuje samozapłon paliwa to podstawowy warunek sformułowania wiarygodnej diagnozy o stanie technicznym przestrzeni roboczych oraz układu zasilania paliwem silnika.

Dla weryfikacji informacyjności diagnostycznej uzyskanych wyników pomiarowych przeprowadzono jednoczesne pomiary ciśnienia cylindrowego oraz drgań generowanych z układu wtryskowego i rozrządu zaworowego silnika.

W wyniku uproszczonej analizy porównawczej uzyskano zadowalającą zgodność jakościową i ilościową zarejestrowanych przebiegów obserwowanych parametrów kontrolnych. Uzyskane doświadczenia badawcze pozwoliły przeprowadzić modernizację technologii pomiaru oraz oprogramowania komputerowego, w taki sposób, że możliwe jest precyzyjne zsynchronizowanie rejestracji wszystkich wielkości pomiarowych, dla dokonania analizy porównawczej ich przebiegów względem położenia kątowego wału korbowego. W kolejnym etapie badań przeprowadzone zostaną dalsze testy diagnostyczne w warunkach zasilania silnika biopaliwem.

\section{Podziękowania}

Badania były finansowane $\mathrm{z}$ budżetu Zadania Badawczego nr 4 pt. „Opracowanie zintegrowanych technologii wytwarzania paliw i energii z biomasy, odpadów rolniczych i innych" w ramach strategicznego programu badań naukowych i prac rozwojowych pt.: „Zaawansowane technologie pozyskiwania energii” realizowanego ze środków NCBiR i ENERGA S.A. Przedstawione w artykule roz- 
out from the resources of NCBiR (National Board for Research ad Development) and ENERGA S.A. A patent application regarding the solution related to the angle of fuel self-ignition presented in the paper has been submitted to the Patent Office of the Republic of Poland. Number of application: P.402669 - 'The system for Monitoring of the angle of fuel self-ignition, particularly in a cylinder of a diesel engine, with the application of the Langmuir probe'. wiązanie pomiaru kąta samozapłonu paliwa zgłoszono do UPRP. Nr zgłoszenia P.402669 pt: „Układ monitorowania kąta samozapłonu paliwa, zwłaszcza w cylindrze silnika o zapłonie samoczynnym z zastosowaniem sondy Langmuira"

\section{Bibliography/Literatura}

[1] Böhme D.K.: Chemical ionization in flames Ion molecular reactions New York: Plenum pp. 323-343, 1972.

[2] Hayhurst A.N., Kittelson D.B.: Combust. Flame 31, pp. 37-51, 1978.

[3] Gooding J.M., Böhme D.K., Ng C.-W.: Combust. Flame 36, pp. 45-62, 1979.

[4] Eraslan A.N., Brown R.C.: Combust. Flame 74, pp. 19-37, 1988

[5] Calcote H.F., Keil D.G.: Pure Appl. Chem. 62, pp. 815-824, 1990.

[6] Pedersen T., Brown R.C.: Combust. Flame 94, pp. 433-448, 1993.

[7] Fialkov A.B.: Prog. Energy Combust. Sci. 23, pp. 399-528, 1997.

[8] Weilmuster P., Keller A., Homann K.-H.: Combust. Flame 116, pp. 62-83, 1999.

[9] Starik A.M., Savel'ev A.M., Titova N.S., Schumann U.: Aerospace Sci. Technol. 6, pp. 63-81, 2002.

[10] Haverkamp H., Wihem S., Sorokin A., Arnold F.: Atmospheric Environment 38, pp. 2879-84, 2004.

[11] Savel'ev A.M., Starik A.M., Titova N.S., Favorskii O.N.: Doclady Physics 49, pp. 441 446, 2004.

[12] Shimasaki Y., et al.: Automotive Engineering 101 (1993), p. 15.

[13] Yu F., Turco R.P.: J. Geophys. Res. 103, pp. 25915-34, 1998.

[14] Fahey D.W., Shumann U., Ackerman S., Artaxo P., Boucher O., Danilin M.Y., Kärcher B., Minnis P., Nakajima T., Toon O.B.: Aviation and the Global Atmosphere, A Special Report of IPCC (Intergovernmental Panel on Climate Change), eds J.E. Penner, D.H. Lister, D.J. Griggs, D.J. Dokken, M. McFarland (UK, Cambridge, Cambridge Univ. Press), pp. 65-120, 1999.

Prof. Zbigniew Korczewski, DSc., DEng. - Head of the Department of Marine and Land Power Plants in the Faculty of Ocean Engineering \& Ship Technology at Gdańsk University of Technology. Prof. dr hab. inż. Zbigniew Korczewski - Kierownik Katedry Silowni Morskich i Ladowych na Wydziale Oceanotechniki i Okrętownictwa Politechniki Gdańskiej.

e-mail: z.korczewski@gmail.com

Jacek Rudnicki, DEng. - Doctor in the Faculty of Ocean Engineering and Ship Technology at Gdańsk University of Technology.

Dr inż. Jacek Rudnicki - adiunkt na Wydziale Oceanotechniki i Okrętownictwa Politechniki Gdańskiej.

e-mail: jacekrud@pg.gda.pl
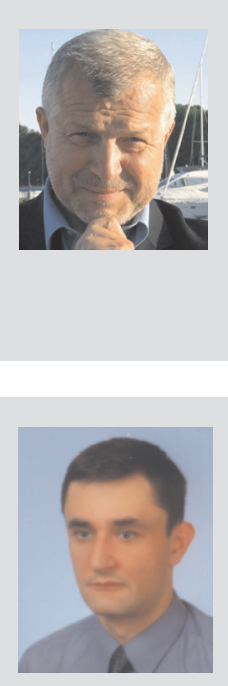

[15] Starik A.M., Savel'ev A.M., Titova N.S.: Proc. of 2nd Int. Workshop on Cold Atmospheric Pressure Plasmas: Sources and Applications (Bruges, Belgium), pp. 118-122, 2005.

[16] Yoshimaya S., Tomita E.: Fundamental study on combustion diagnostics using a spark plug as an ion probe, SAE Technical Paper 2000-01-2828, 2000.

[17] Sotton J., Labuda S.A., Ruttun B., Bellenoue M.: 30th Int. Symp. on Combustion, W-I-P, p. 241, 2004.

[18] Bellenoue M., Cenian A., Kageyama T., Labuda S.A., Leys C.: J. Tech. Phys. 44, 363, 2003.

[19] Rodrigues J.M., Agneray A., Jaffrézic X., Bellenoue M., Labuda S., Leys C., Chernukho A.P., Migoun A.N., Cenian A., Starik A.M., Titova N.S., Savel'ev A.M.: Evolution of charged species in propane/air flames - mass-spectrometric analysis and modelling, Plasma Sources Sci. Technol. 16, pp. 161-172, 2007.

[20] Estefanous F.A.: Ionization in Diesel combustion: mechanism, new instrumentation and engine applications, $\mathrm{PhD}$ thesis (UMI Number: 3466645), Graduate School of Wayne State University, Detroit, Michigan, 2011.

[21] Cenian A.: Diagnostyka procesu spalania węglowodorów. Raport końcowy projektu badawczego PB1071/T10/2002/22. IMP PAN, Gdańsk 2002.

[22] Maclatchy C.S.: Charge depletion downstream of a cylindrical Langmuir probe immersed in flowing, high-pressure plasma. IEEE Transactions on Plasma Science, Vol. 17, No. 1. February 1989.

[23] Maclatchy C.S., Smith H.C.L.: The electron current to a Langmuir probe in flowing high-pressure plasma. IEEE Transactions on Plasma Science, Vol. 19, No. 6, 1991.

[24] Rychter T., Teodorczyk A.: Teoria silników tłokowych. WKiも, Warszawa 2006.

Leszek Piechowski, MEng. - chief specialist at the Chair of Physical Aspects of Ecoenergy, The Szewalski Institute of Fluid-Flow Machinery PASci., Gdańsk.

Mgr inż. Leszek Piechowski - starszy specjalista w zakladzie Fizycznych Podstaw Ekoenergii w Instytucie Maszyn Przeplywowych PAN im. R. Szewalskiego w Gdańsku.

e-mail: leszek.piechowski@imp.gda.pl

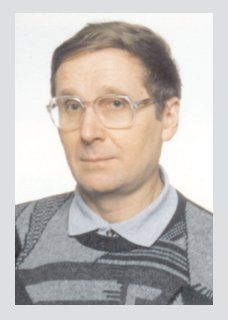

Adam Cenian, DSc., DEng. - chief specialist at the Chair of Physical Aspects of Ecoenergy, The Szewalski Institute of Fluid-Flow Machinery PASci., Gdańsk.

Dr hab. inż. Adam Cenian - profesor IMP PAN $i$ kierownik zakladu Fizycznych Podstaw Ekoenergii w Instytucie Maszyn Przeplywowych PAN im. R. Szewalskiego w Gdańsku. e-mail: adam.cenian@imp.gda.pl 